
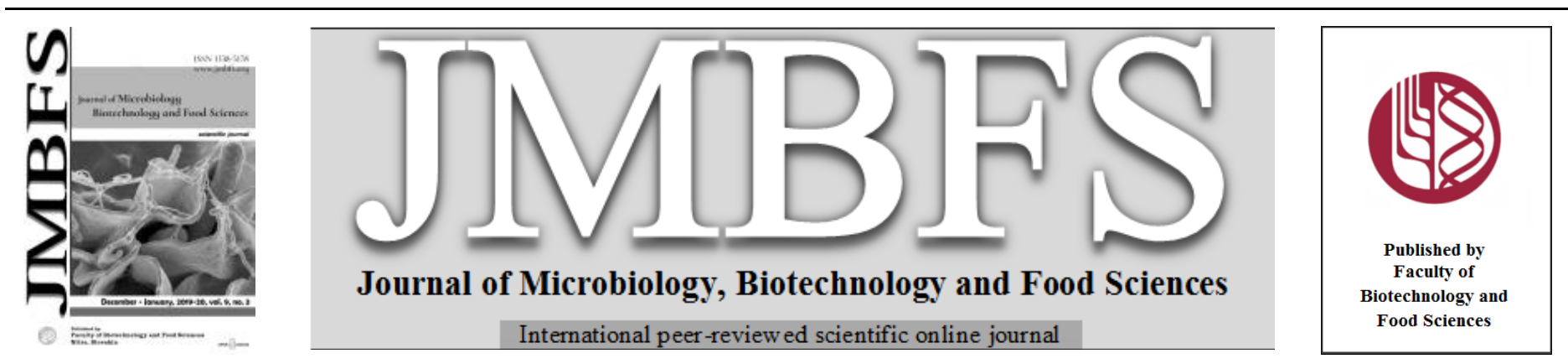

\title{
SLAUGHTER CHARACTERISTICS AND PHYSICAL TECHNOLOGICAL PARAMETERS OF VEAL FROM MALE CALVES OF HOLSTEIN AND SLOVAK SIMMENTAL BREEDS
}

\author{
Klára Vavrišinovál, Katarina Hozákovál ${ }^{*}$, Ondřej Bučko ${ }^{1}$, Jana Tkáčová2, Marek Bobko ${ }^{2}$
}

Address(es): Ing. Katarína Hozáková,

${ }^{1}$ Slovak Agricultural University, Faculty of Agrobiology and Food Resources, Department of Animal Husbandry, Tr. A. Hlinku 2, 94976 Nitra, Slovak republic, +421 376414411.

${ }^{2}$ Slovak Agricultural University, Faculty of Biotechnology and Food Sciences, Department of Evaluation and Processing of Animal Products, Tr. A. Hlinku 2, 94976 Nitra, Slovak Republic.

*Corresponding author: xsupekovak@uniag.sk

doi: 10.15414/jmbfs.2019/20.9.3.634-638

ARTICLE INFO

Received 22. 5. 2019

Revised 2. 9. 2019

Accepted 2. 9. 2019

Published 1. 12. 2019

Regular article

open 2 access

\begin{abstract}
Monitoring of selected carcass parameters and analysing of qualitative parameters of veal calves has become an object of concern. The aim of this experiment was to evaluate slaughter parameters, proximate composition and physical technological parameters of Musculus longissimus thoracis (MLT) and Musculus semimembranosus (SM) from calves of two different utility types: Holstein (H) and Slovak Simmental breed (S). The calves were reared under the same housing conditions. All animals were fed with alfalfa hay, feed straw and feed mixture, with ad libitum access to free water. The fattening period started from weaning (about 60 days of age) to required final weight. Total length of the fattening period was about 150 days. No significant differences in the slaughter weight (P>0.05), carcass weight $(\mathrm{P}>0.05)$ and dressing percentage $(\mathrm{P}>0.05)$ were revealed. Higher content of rumen and intestinal fat was observed in the Holstein veal calves $(\mathrm{P}>0.05)$, whereas content of kidney fat was higher in the $\mathrm{S}$ calves $(\mathrm{P}<0.05)$. Higher differences were found in the proportions of technical bones $(\mathrm{P}<0.01)$ and proportion of meat from right- half carcass $(\mathrm{P}<0.05)$, but no significant differences in the proportion of marrow bones $(\mathrm{P}>0.05)$ and separable fat $(\mathrm{P}>0.05)$ were found. No significant differences were found in the most valuable meat cuts - tenderloin, sirloin, round meat $(\mathrm{P}>0.05)$. As regards the chemical analysis of the loin muscle, significant differences in moisture content were revealed $(\mathrm{P}<0.01)$. Holstein calves had higher content of intramuscular fat $(\mathrm{P}>0.05)$ in both the muscles. Energy value of MLT was greater in the Holstein; however results were not significant $(\mathrm{P}>0.05)$. Concentration of MDA in samples increased during 9 days of storage which is normal due to the ageing process of the meat. Higher degradation of lipids after 9 days of storage was found in samples from Holstein veal $(\mathrm{P}>0.05)$. Statistical significant variety of the $\mathrm{pH}_{1}(\mathrm{P}<0.001)$ and $\mathrm{pH}_{24}(\mathrm{P}<0.001)$ values as well as drip loss value $(\mathrm{P}<0.01)$ were found. Cooked samples of MLT were tenderer in Holstein calves $(\mathrm{P}<0.001)$ which are consistent with higher content of intramuscular fat. Samples of top round muscle were tougher $(\mathrm{P}<0.05)$.In colour spectrum of MLT after 7 days after slaughter was observed darker (CIE $\left.L^{*} ; \mathrm{P}<0.01\right)$ and redder ( $\left.\mathrm{CIE} a * ; \mathrm{P}>0.05\right)$ meat in the $\mathrm{S}$ male calves which had also higher electrical conductivity -2 value $(\mathrm{P}<0.001)$.
\end{abstract}

Keywords: ageing, bulls, fattening, physical technological parameters, shear force

\section{INTRODUCTION}

A downward trend in the number of reared livestock results in reduced interest in breeding as well as milk and meat production. Meat as a nutritive is a highly valued component of human nutrition. Beef is a valuable resource of nutrients which are necessary for human organism (calcium, vitamin $\mathrm{C}$, folic acid, etc.). Bovine and veal muscle contain approximately the same amount of total proteins (21.48 vs. $\left.21.37 \mathrm{~g} .100 \mathrm{~g}^{-1}\right)$. Veal has a lower intramuscular fat content $\left(1.28 \mathrm{~g} .100 \mathrm{~g}^{-1}\right)$ and cholesterol $\left(0.070 \mathrm{~g} .100 \mathrm{~g}^{-1}\right)$ in comparison with beef (4.29g.100 g of intramuscular fat; $0.60 \mathrm{~g} .100 \mathrm{~g}^{-1}$ of cholesterol) as well as approximately the same amount of trace elements. The content of essential amino acids in veal is approximately $7.43 \mathrm{~g} .100 \mathrm{~g}^{-1}$ (Vojtaššáková $\boldsymbol{e t ~ a l . , ~ 2 0 0 2 ) . ~ T h e ~ m e a t ~}$ nutritional value is given by the protein and intramuscular fat content in animal muscles. The purpose of fattening calves is to achieve a higher live weight with a very good quality and taste of veal (Sommer, 1975). Under sort, resp. quality of meat we understand measurable properties of muscles - microbiological state, tenderness, colour, juiciness, shelf life and $\mathrm{pH}$ value. On the other hand, the overall quality of meat and meat products is influenced by personal perception of value by consumers (Feiner, 2006). Tenderness, softness, texture and taste are considered to be the most important quality traits (Çatikkaş and Koç, 2017). But sensory attributes,such as meat and fat colour, texture and taste decide about the purchase. These factors are influenced both by the rate of growth and management of slaughterbut also by biochemical and microbiological changes during storage (Palo et al., 2014). White and pink veal is very popular abroad, especially in France, Italy, Belgium, Netherland and Germany and is one of the highly valued culinary specialities (Vieira et al., 2005). The final product has unique properties and very fine and soft taste (Ngapo and Gariépy, 2006). According to Council Regulation (EC) No 566/2008 veal in European countries differentiates into two categories. White veal (milk-fed veal; special-fed veal) derived from calves under 8 months of age. Second category is pink, resp. 'rosé' veal from calves which are no more than 8 months old. Rosé veal has a darker colour of meat depending on nutrition. Atpresent specialized fattening of calves known from abroad is not done in Slovakia. In particular there are reared calves about live weight of 50-60 to $80 \mathrm{~kg}$ inappropriate for further breeding (Čítek and Šch, 2002). Veal in Slovakia is obtained from carcasses of juvenile individuals up to a weight of $150 \mathrm{~kg}$ either from milk calves up to 6 weeks of age (minimal weight $25 \mathrm{~kg}$ ), fattening calves from 6 weeks to 6 months of age (weight of at least $70 \mathrm{~kg}$ ) or from calves older than 6 months (MASR, 2002). Several producers are fattening calves according to the market requirements. According to Decree No 730/2002 it is not possible to produce required soft pink meat because the law clearly sets minimum standards for the protection of calves for meat production. This law determines administration of feed with a sufficient content of roughage to provide blood haemoglobin level of $4.5 \mathrm{mmol}^{-1}$.

Therefore, it is necessary to bring knowledge about the quality of veal slaughtered in Slovakia and to mention the quality traits of meat from different breeds. 


\section{MATERIAL AND METHODOLOGY}

\section{Biological material and sample preparation}

The experiment included a total of 10 young bulls of Holstein $(\mathrm{H})$ and 10 young bulls of Slovak Simmental (S). Animals were reared at local farm, where they were kept in individual boxes during the first stage of the experiment (to the weaning). The calves were fed with dairy feed mixture and the starter feed mixture ad libitum. After this stage (about 60 days) they were weaned and housed together in barns in 2 groups divided by breed. Calves in both groups were fed with alfalfa hay, feed straw and feed mixture. Drinking water was available from birth ad libitum. Both calves were slaughtered after 150 days of fattening at required weight. The calves were chosen randomly. The calves were dressed in a slaughterhouse by trained professional in accordance with standard methods, using a captive bolt stunner, sticking and bleeding. The carcasses were immediately chilled at $4{ }^{\circ} \mathrm{C}$ for $24 \mathrm{~h}$ after slaughter in a chilling room. The average live and carcass weight in the Holstein group was 133.8 and $70.16 \mathrm{~kg}$ while in Slovak Simmental group was average 135.60 and $71.98 \mathrm{~kg}$. Afterwards, detailed dissection was carried out from right - half carcasses into primal cuts Weight in primal cuts of both groups from hindquarter and forequarter were obtained. Also, weight and percentage in individual tissues of meat were observed. The samples of meat from Musculus longissimus dorsi (MLD) was taken for qualitative parameters, immediately after weighting. From this sample at the level of $9^{\text {th }}$ thoracic vertebra, the MLD area was planimetrically evaluated Immediately, slices of m.longissimus thoracis (MLT) and top round ( $m$. semimembranosus) muscles were taken for physical technological analysis.

\section{Proximate composition}

Immediately after chilling, samples from MLT were analyzed for proximate composition, specifically moisture, proteinand intramuscular fat using spectrometer Nicolet 6700 . The energy value in $100 \mathrm{~g}$ of meat was calculated from the content of protein and intramuscular fat. Energy value was calculated as follows: $\mathrm{EV}\left(\mathrm{kJ} .100 \mathrm{~g}^{-1}\right)=(16.75 \mathrm{x}$ amount of proteins $)+(37.68 \mathrm{x}$ amount of intramuscular fat).

\section{Physical chemical analysis}

The $\mathrm{pH}$ values of samples $\left(\mathrm{pH}_{1}\right.$ and $\mathrm{pH}_{24}$ hour post mortem) were investigated using Titan $\mathrm{pH}$ meter Hanna HI99161 in $\log \cdot \operatorname{molc}^{(\mathrm{H+})}{ }^{-1}$. The electrical conductivity of samples was measured with instrument Tecpro in $\mu{\mathrm{S} . \mathrm{cm}^{-1}}^{-1}$ The percentage of free water was calculated from samples as drip loss. The meat colour was measured at the fresh section using spectrophotometric device Minolta CM 2600 D (Konica Minolta, Japan). Lipid oxidation in MLT and top round samples was assessed as thiobarbituric acid reactive-substances (TBARS). Results were measured as amount of malondialdehyde in mg. $\mathrm{kg}^{-1}$ of muscle in the process of $1^{\text {st }}, 3^{\text {rd }}, 6^{\text {th }}$ and $9^{\text {th }}$ day of storage. TBA value was determined by Marcinčák et al. (2006). Afterwards, the Warner-Bratzler shear force (WBSF) was recorded on cooked meat in kg.cm ${ }^{-2}$ using Warner-Bratzler shear force device (Chatillon, USA) as describes Haščí et al. (2015). Meat samples of 150-200 g were cooked in water bath until they reached an internal temperature of $70^{\circ} \mathrm{C}$ for the 30 minutes. From cooked meat were cut cores $(10$ x10 x80 mm $)$ and subsequently sheared perpendicularly to the muscle fibres direction. The cooking loss was expressed with percentage of weight loss after cooking as follows: Cooking loss $(\%)=($ final cooked weight- raw weight $)-100$.

\section{Statistics}

Basic variability and statistical characteristics were calculated using the Statistical Analysis System (SAS) version 9.3 (TS1M2) Enterprise Guide 5.1 (SAS INSTITUTE Inc., 2011). For the impact of the verification was used t-test. Results were reported as means and standarddeviations.

\section{RESULTS AND DISCUSSION}

The slaughter performance of the Holstein and Slovak Simmental male calves is presented in Table 1 . The $\mathrm{S}$ young bulls had higher growth intensity $(\mathrm{P}>0.05)$ at the end of fattening (live weight of $147.6 \mathrm{~kg}$ ) than those of the Holstein (live weight of $143.6 \mathrm{~kg}$ ). After 12 hours we found no significant differences inthe average carcass weight of both genotypes ( $\mathrm{S} 135.6 \mathrm{~kg}, \mathrm{H} 133.8 \mathrm{~kg}$ ). The results showed the similarity in the growth rate of $\mathrm{H}$ and $\mathrm{S}$ young bulls with the same nutrition. Likewise, the dressing percentage of both calves was similar in this study ( $\mathrm{P}>0.05$ ), although, the average carcass weight was greater in the Slovak Simmental $(71.32 \pm 7.09 \mathrm{~kg})$ than in the Holstein $(\mathrm{P}>0.05)$. According to Barton $\boldsymbol{e}$ al. (2003) the carcass value is probably decreasing with an increasing milking utility and genotype representation in milking herds. Authors showed lower dressing percentage in the Holstein (54.88\%) compared with the Czech pied cattle $(57.29 \%)$

$\underline{\text { Table } 1 \text { Slaughter parameters of veal from Holstein and Slovak Simmental male calves }}$

\begin{tabular}{lccc}
\hline & Holstein $(\mathrm{n}=10)$ & Slovak Simmental $(\mathrm{n}=10)$ & Sign. \\
\hline Final weight $(\mathrm{kg})$ & $143.60 \pm 6.43$ & $147.60 \pm 11.87$ & $n s$ \\
\hline Slaughter weight $(\mathrm{kg})$ & $133.80 \pm 6.23$ & $135.60 \pm 9.79$ & $n s$ \\
\hline Average carcass weight $(\mathrm{kg})$ & $71.15 \pm 3.46$ & $71.32 \pm 7.09$ & $n s$ \\
\hline Dressing percentage $(\%)$ & $53.19 \pm 1.57$ & $52.50 \pm 1.61$ & $n s$ \\
\hline
\end{tabular}

Legend: * $\mathrm{P}>0.05,{ }^{*} \mathrm{P}<0.01, * * * \mathrm{P}<0.001$, ns not significant, \% values were calculated from slaughter weight

Table 2 represents selected parameters of right - half carcass dissection. Calves of the $\mathrm{H}$ had higher proportion of rumen fat $(\mathrm{P}>0.05)$, almost the same proportion of intestinal fat $(\mathrm{P}>0.05)$, while the $\mathrm{S}$ calves had higher proportion of kidney fat $(\mathrm{P}<0.01)$. Vavrišínová et al. (2013) noted higher values in proportions of visceral fatin Holstein calves. Proportions of head, skin and limbs (separated in a knee or elbow joint) were higher in the Slovak Simmental calves $(\mathrm{P}<0.001)$.

Table 2 Weights and percentage of parts not included to the meat of calves from monitored breeds

\begin{tabular}{|c|c|c|c|c|c|c|}
\hline & \multicolumn{2}{|c|}{ Weight (kg) } & \multirow{2}{*}{ Sign. } & \multicolumn{2}{|c|}{ Percentage (\%) } & \multirow{2}{*}{ Sign } \\
\hline & $\mathrm{H}(\mathrm{n}=10)$ & $S(n=10)$ & & $\mathrm{H}(\mathrm{n}=10)$ & $\mathrm{S}(\mathrm{n}=10)$ & \\
\hline Rumen fat & $0.34 \pm 0.10$ & $0.28 \pm 0.09$ & $n s$ & $0.26 \pm 0.07$ & $0.21 \pm 0.07$ & $n s$ \\
\hline Intestinal fat & $0.19 \pm 0.07$ & $0.18 \pm 0.06$ & $n s$ & $0.14 \pm 0.04$ & $0.14 \pm 0.06$ & $n s$ \\
\hline Kidney fat & $0.51 \pm 0.10$ & $0.77 \pm 0.26$ & $*$ & $0.38 \pm 0.07$ & $0.57 \pm 0.18$ & ** \\
\hline Head & $7.26 \pm 0.24$ & $8.32 \pm 0.63$ & $* * *$ & $5.43 \pm 0.17$ & $6.14 \pm 0.16$ & $* * *$ \\
\hline Skin & $8.94 \pm 0.71$ & $10.30 \pm 0.92$ & $* *$ & $6.68 \pm 0.43$ & $7.59 \pm 0.26$ & $* * *$ \\
\hline Limbs & $3.60 \pm 0.27$ & $4.39 \pm 0.44$ & $* * *$ & $2.69 \pm 0.22$ & $3.24 \pm 0.20$ & $* * *$ \\
\hline
\end{tabular}

Legend: $* \mathrm{P}>0.05, * * \mathrm{P}<0.01, * * * \mathrm{P}<0.001$, ns not significant, \% values were calculated from slaughter weight

As shown in Table 3, the MLD area was higher in the $\mathrm{S}\left(35.02 \mathrm{~cm}^{2}\right)$ than in the $\mathrm{H}$ $\left(29.96 \mathrm{~cm}^{2}\right)$. Our results are similar to those of Vavrišínová et al. (2013), who reported the MLD area in the Holstein veal $29.88 \mathrm{~cm}^{2}$. In terms of valuable primal cuts from right - half carcasses, calves from $\mathrm{S}$ had higher weights of round meat, tenderloin as well as sirloin; however, no significant differences were observed. Yim et al. (2015b) noted for the Holstein calves of 5 month of age higher weight of tenderloin $(1.3 \mathrm{~kg})$.

Weight $(\mathrm{P}>0.05)$ and proportion $(\mathrm{P}<0.05)$ of meat from the right - half carcass (represented in Table 4) were higher in the Slovak Simmental calves $(67.56 \%$ vs $66.03 \%$ ). Total amount of separable fat and technical bones was greater in the
$S$ young bulls $(\mathrm{P}>0.05)$. Proportion of marrow bones were similar in both of the calves $(\mathrm{P}>0.05)$. In the $\mathrm{H}$ calves, we observed amount of the meat $23.49 \mathrm{~kg}$, bones $9.72 \mathrm{~kg}$ and separable fat $2.38 \mathrm{~kg}$ at the average slaughter weight of $133.8 \mathrm{~kg}$. Our results are similar to those shown by Santos et al. (2013) for proportion of the meat, either more favourable for proportion of the fat. Bartoň et al. (2003) showed that bulls from Czech pied breed have strongly more efficient meat production in the higher slaughter weight than bulls from Holstein. In terms of the proportion of valuable meat parts we can see better results in the Slovak Simmental male calves. 
Table 3 Proportion of most valuable primal cuts of the right carcass half

\begin{tabular}{|c|c|c|c|c|c|c|}
\hline & \multicolumn{2}{|l|}{ Weight (kg) } & \multirow{2}{*}{ Sign. } & \multicolumn{2}{|c|}{ Percentage (\%) } & \multirow{2}{*}{ Sign. } \\
\hline & $\mathrm{H}(\mathrm{n}=10)$ & $\mathrm{S}(\mathrm{n}=10)$ & & $\mathrm{H}(\mathrm{n}=10)$ & $\mathrm{S}(\mathrm{n}=10)$ & \\
\hline Round meat (with bone) & $12.89 \pm 0.56$ & $13.53 \pm 1.20$ & $n s$ & $36.24 \pm 0.37$ & $38.53 \pm 0.50$ & $n s$ \\
\hline Shoulder (with bone) & $6.58 \pm 0.21$ & $6.37 \pm 0.59$ & $n s$ & $18.51 \pm 0.84$ & $18.15 \pm 0.56$ & $* * *$ \\
\hline Shoulder (boneless) & $3.99 \pm 0.12$ & $2.63 \pm 0.35$ & $n s$ & $11.22 \pm 0.50$ & $7.47 \pm 0.46$ & $* *$ \\
\hline Tenderloin (boneless) & $0.62 \pm 0.04$ & $0.63 \pm 0.10$ & $n s$ & $1.75 \pm 0.05$ & $1.77 \pm 0.17$ & $n s$ \\
\hline Sirloin (with bone) & $2.56 \pm 0.25$ & $2.72 \pm 0.36$ & $n s$ & $7.18 \pm 0.58$ & $7.72 \pm 0.62$ & $n s$ \\
\hline Sirloin (boneless) & $1.21 \pm 0.14$ & $1.34 \pm 0.20$ & $n s$ & $3.40 \pm 0.35$ & $3.79 \pm 0.28$ & $n s$ \\
\hline MLD area $\left(\mathrm{cm}^{2}\right)$ & $29.96 \pm 8.27$ & $35.02 \pm 4.49$ & $n s$ & & & \\
\hline
\end{tabular}

Legend: * $\mathrm{P}>0.05, * * \mathrm{P}<0.01, * * * \mathrm{P}<0.001$, ns not significant, \% values were calculated from right - half carcass weight

Table 4 Proportion of tissues from right carcass half from $\mathrm{H}$ and $\mathrm{S}$ calves

\begin{tabular}{|c|c|c|c|c|c|c|}
\hline & \multicolumn{2}{|l|}{ Weight (kg) } & \multirow{2}{*}{ Sign. } & \multicolumn{2}{|c|}{ Percentage $(\%)$} & \multirow{2}{*}{ Sign } \\
\hline & $\mathrm{H}(\mathrm{n}=10)$ & $\mathrm{S}(\mathrm{n}=10)$ & & $H(n=10)$ & $\mathrm{S}(\mathrm{n}=10)$ & \\
\hline Meat from right - half carcass & $23.49 \pm 1.08$ & $23.71 \pm 2.05$ & $n s$ & $66.03 \pm 1.16$ & $67.56 \pm 1.41$ & $*$ \\
\hline Marrowbones & $4.41 \pm 0.18$ & $4.47 \pm 0.28$ & $*$ & $12.04 \pm 0.66$ & $12.75 \pm 0.58$ & $n s$ \\
\hline Technical bones & $5.31 \pm 0.37$ & $5.61 \pm 0.75$ & $n s$ & $14.91 \pm 0.62$ & $15.91 \pm 0.75$ & $* *$ \\
\hline Separable fat & $2.38 \pm 0.33$ & $2.54 \pm 0.52$ & $n s$ & $6.65 \pm 0.70$ & $7.20 \pm 0.98$ & $n s$ \\
\hline
\end{tabular}

Legend: $* \mathrm{P}>0.05, * * \mathrm{P}<0.01,{ }^{*} * * \mathrm{P}<0.001, \mathrm{~ns}$ not significant, $\%$ values were calculated from right - half carcass weight

Moisture content of the MLT muscle (Table 5) was higher in the Slovak Simmental calves than in the Holstein sample $(\mathrm{P}<0.01)$. Holstein calves had higher protein content as well as content of intramuscular fat (IMF) in samples of MLT, but no significant differences were observed $(\mathrm{P}>0.05)$. In terms of top round muscle, $S$ calves had lower moisture content $(\mathrm{P}>0.05)$. In accordance with our findings Yim et al. (2015b) reported, that increase of the intramuscular fat content in the muscle causes decrease in the water content. The water content of the meat in the $\mathrm{H}$ was lower compared to the results by Cho et al. (2014) but also similar in the protein $(22.30 \%)$ and intramuscular fat $(1.42 \%)$ content. Energy value of the loin muscle was greater in the $\mathrm{H}$ sample $(\mathrm{P}>0.05)$ which is consistent with higher IMF content.

Table 5 Proximate composition and energy value of MLT and Top round muscles in Holstein and Slovak Simmental calves

\begin{tabular}{|c|c|c|c|c|c|c|}
\hline & \multicolumn{2}{|l|}{ MLT } & \multirow{2}{*}{ Sign. } & \multicolumn{2}{|l|}{ Top round } & \multirow{2}{*}{ Sign. } \\
\hline & $\mathrm{H}(\mathrm{n}=10)$ & $\mathrm{S}(\mathrm{n}=10)$ & & $\mathrm{H}(\mathrm{n}=10)$ & $\mathrm{S}(\mathrm{n}=10)$ & \\
\hline Protein $(\%)$ & $22.85 \pm 0.62$ & $22.62 \pm 1.25$ & $n s$ & $21.83 \pm 0.47$ & $23.45 \pm 2.15$ & $n s$ \\
\hline Moisture (\%) & $74.88 \pm 0.67$ & $76.06 \pm 1.05$ & $* *$ & $75.89 \pm 0.74$ & $75.56 \pm 1.08$ & $n s$ \\
\hline IMF (\%) & $1.69 \pm 0.30$ & $1.54 \pm 0.69$ & $n s$ & $1.84 \pm 0.13$ & $1.27 \pm 0.52$ & $n s$ \\
\hline $\mathrm{EV}\left(\mathrm{kJ} .100 \mathrm{~g}^{-1}\right)$ & $446.23 \pm 18.52$ & $436.69 \pm 26.01$ & $n s$ & $435.06 \pm 10.76$ & $440.50 \pm 34.38$ & $n s$ \\
\hline
\end{tabular}

Legend: $* \mathrm{P}>0.05, * * \mathrm{P}<0.01, * * * \mathrm{P}<0.001, \mathrm{~ns}$ not significant

Changes in the concentration of MDA in $m$. longissimus thoracis and $m$. semimembranosus of the Holstein and Slovak Simmental veal during storage are shown in Table 6. MDA values during the first day of storage were higher in the $\mathrm{H}$ veal in samples of MLT $(\mathrm{P}<0.05)$ as well as top round muscle $(\mathrm{P}<0.001)$. Oxidation levels of MLT in the Holstein increased to an approximately 1.07 mg. $\mathrm{kg}^{-1}$ after 6 days $(\mathrm{P}<0.01)$. Comparison of the changes in MDA, values of the lipid oxidation were higher in the Holstein than in the $\mathrm{S}$ during 9 days of storage in both samples. Skřivanová et al. (2007) found higher values of MDA after 3 days of storage in Holstein veal slaughtered at final weight of $163.5 \mathrm{~kg}(0.83$ $\left.\mathrm{mg} \cdot \mathrm{kg}^{-1}\right)$.

Table 6 Concentration of malondialdehyde $\left(\mathrm{mg}_{\mathrm{kg}} \mathrm{kg}^{-1}\right)$ in MLT and top round muscles in veal of Holstein and Slovak Simmental during storage

\begin{tabular}{|c|c|c|c|c|c|c|}
\hline \multirow{2}{*}{ Time of storage } & \multicolumn{2}{|l|}{ MLT } & \multirow{2}{*}{ Sign. } & \multicolumn{2}{|l|}{ Top round } & \multirow{2}{*}{ Sign. } \\
\hline & $\mathrm{H}(\mathrm{n}=10)$ & $\mathrm{S}(\mathrm{n}=10)$ & & $\mathrm{H}(\mathrm{n}=10)$ & $\mathrm{S}(\mathrm{n}=10)$ & \\
\hline Day - 1 & $0.05 \pm 0.02$ & $0.03 \pm 0.00$ & * & $0.07 \pm 0.02$ & $0.03 \pm 0.01$ & $* * *$ \\
\hline Day -3 & $0.55 \pm 0.09$ & $0.60 \pm 0.17$ & $n s$ & $0.79 \pm 0.06$ & $0.89 \pm 0.27$ & $n s$ \\
\hline Day -6 & $1.07 \pm 0.21$ & $0.81 \pm 0.19$ & $* *$ & $1.50 \pm 0.12$ & $1.24 \pm 0.34$ & $*$ \\
\hline Day -9 & $1.79 \pm 0.29$ & $1.10 \pm 0.18$ & $n s$ & $2.39 \pm 0.15$ & $1.59 \pm 0.31$ & $n s$ \\
\hline
\end{tabular}

Legend: $* \mathrm{P}>0.05, * * \mathrm{P}<0.01, * * * \mathrm{P}<0.001$, ns not significant

Table 7 represents some physical chemical properties of MLT and top round $(\mathrm{m}$ semimembranosus) muscle. Drip loss of MLT muscle was significantly higher in the $\mathrm{S}$ than in the $\mathrm{H}$ calves $(\mathrm{P}<0.01)$. Jeremiah et al. (2003) noted an inverse relationship between water-holding capacity and IMF content. The ability of meat to retain inherent water - water holding capacity (WHC), is one of the most important characteristics, which determines meat quality and utilization. Meat with good WHC differs from meat with reduced ability (poor quality) mainly by differences in the physical state of proteins. With increasing value of $\mathrm{pH}$, and thus more distant from the protein isoelectronic point, is the ability to immobilize a larger amount of water greater (Jedlička, 1988; Pipek, 1998; Steinhauser $\boldsymbol{e}$ al., 2000). On the other hand, the lowest WHC is in the isoelectronic point of the protein. The $\mathrm{pH}$ values were detected 1 and 24 hours after slaughter. Higher values of $\mathrm{pH}_{24}$ were found in the $\mathrm{H}$ in both muscles $(\mathrm{P}<0.001)$. Even though the $\mathrm{pH}$ value of the $\mathrm{H}$ does not exceed limit 6.2, which several authors consider as border for undesirable meat defects, it is possible to state (in agreement with other authors) (Franc et al., 1988), that the qualitative deviations in the meat are only a matter of individual muscles and not the entire carcass. The results of free water and electrical conductivity also corresponded to the values. Chládek and Ingr (2003) reported in the Holstein steers slaughtered between 10 to 12 months values of $\mathrm{pH}_{24} 5.50$ and drip loss $1.66 \%$. Cooking loss in top round muscle were similar between calves of both groups $(\mathrm{P}>0.05)$. Cooking of samples from MLT to internal temperature of $70{ }^{\circ} \mathrm{C}$ resulted in higher cooking loss $(28.97 \%-\mathrm{H}$,
$29.31 \%$ - S; P<0.05). Li et al. (2018) also showed cooking loss of $29 \%$ in veal samples heated to $71.1^{\circ} \mathrm{C}$

The meat ageing is indispensable in the process of the tenderisation. In comparison with other meats, veal has acceptable texture and requires less time to reach the same level of tenderness (Ngapo and Gariépy, 2006). WarnerBratzler shear force values of both the muscles (Table 7) were lower in the Holstein than in the Slovak Simmental $(\mathrm{P}<0.001-$ MLT; $\mathrm{P}<0.05-\mathrm{SM})$. Cooked samples of MLT were tenderer in Holstein calves $(\mathrm{P}<0.001)$. In agreement with several authors, it could be stated that the tenderness of the meat is related to a number of factors; $\mathrm{pH}$ value is one the most important one (Pérez - Chabela $\boldsymbol{e t}$ al., 2005; Mojto and Zaujec, 2003; Augistini and Fischer, 2000). Tough meat is described by Bruce $\boldsymbol{e t}$ al. (2001), as a result of a very rapid decline of $\mathrm{pH}$ value. The meat tenderness is influenced by the rate of glycolysis, temperature drop after slaughter and changes in $\mathrm{pH}$. Our values of top round muscle are different to those for the Holstein veal reported by Yim et al. (2015a). The shear force can be influenced by interaction between cooking temperature and ageing of meat, as reported Ngapo and Gariépy (2006), while greater ageing on vea cooked to a higher core temperature $\left(60^{\circ} \mathrm{C}\right)$. In addition, according to various authors (Fiems et al., 2000; Yim et al., 2015a) shear force is in correlation with IMF content. 
Table 7 Qualitative parameters of top round and MLT muscles in veal of Holstein and Slovak Simmental

\begin{tabular}{|c|c|c|c|c|c|c|c|}
\hline & & \multicolumn{2}{|l|}{ MLT } & \multirow{2}{*}{ Sign. } & \multicolumn{2}{|l|}{ Top round } & \multirow{2}{*}{ Sign } \\
\hline & & $\mathrm{H}(\mathrm{n}=10)$ & $\mathrm{S}(\mathrm{n}=10)$ & & $\mathrm{H}(\mathrm{n}=10)$ & $\mathrm{S}(\mathrm{n}=10)$ & \\
\hline \multicolumn{2}{|l|}{$\mathrm{pH}_{1}$} & $6.31 \pm 0.09$ & $6.65 \pm 0.14$ & $* * *$ & $6.33 \pm 0.10$ & $6.83 \pm 0.05$ & $* * *$ \\
\hline \multicolumn{2}{|l|}{$\mathrm{pH}_{24}$} & $6.13 \pm 0.11$ & $5.78 \pm 0.10$ & $* * *$ & $6.00 \pm 0.13$ & $5.67 \pm 0.13$ & $* * *$ \\
\hline \multicolumn{2}{|l|}{ Drip loss $(\%)$} & $1.54 \pm 0.51$ & $2.31 \pm 0.53$ & $* *$ & & & \\
\hline \multicolumn{2}{|l|}{ Cooking loss (\%) } & $28.97 \pm 3.57$ & $28.07 \pm 5.53$ & $n s$ & $29.31 \pm 1.72$ & $28.39 \pm 3.37$ & $n s$ \\
\hline \multicolumn{2}{|c|}{ WB shear force $\left(\mathrm{kg} . \mathrm{cm}^{-2}\right)$} & $3.99 \pm 1.41$ & $10.81 \pm 2.71$ & $* * *$ & $5.72 \pm 1.98$ & $8.12 \pm 3.34$ & $*$ \\
\hline \multicolumn{2}{|l|}{$\mathrm{EC}-1(\mu \mathrm{S})$} & $2.66 \pm 0.72$ & $2.92 \pm 0.88$ & $n s$ & $3.70 \pm 0.34$ & $3.84 \pm 0.82$ & $n s$ \\
\hline \multicolumn{2}{|l|}{$\mathrm{EC}-2(\mu \mathrm{S})$} & $2.06 \pm 0.46$ & $3.10 \pm 0.66$ & $* * *$ & $2.60 \pm 0.46$ & $3.48 \pm 0.57$ & $* *$ \\
\hline \multirow{3}{*}{ Meat colour $24 \mathrm{~h}$} & CIE $L^{*}$ & $47.10 \pm 4.06$ & $47.33 \pm 4.07$ & $n s$ & $48.50 \pm 3.87$ & $47.19 \pm 2.15$ & $n s$ \\
\hline & $\mathrm{CIE} a^{*}$ & $5.36 \pm 1.43$ & $3.61 \pm 1.70$ & $*$ & $4.58 \pm 0.62$ & $3.29 \pm 1.53$ & $*$ \\
\hline & $\mathrm{CIE} b^{*}$ & $12.16 \pm 2.24$ & $9.45 \pm 1.44$ & $* *$ & $12.02 \pm 1.32$ & $9.15 \pm 0.31$ & $* * *$ \\
\hline \multirow{3}{*}{ Meat colour 7d } & CIE $L^{*}$ & $61.28 \pm 7.05$ & $52.46 \pm 4.63$ & $* *$ & $61.08 \pm 3.52$ & $48.38 \pm 2.18$ & $* * *$ \\
\hline & $\mathrm{CIE} a^{*}$ & $-5.80 \pm 17.44$ & $1.66 \pm 2.96$ & $n s$ & $-6.69 \pm 10.51$ & $3.19 \pm 2.88$ & $*$ \\
\hline & $\mathrm{CIE} b^{*}$ & $-12.06 \pm 2.22$ & $10.28 \pm 1.43$ & $* * *$ & $-12.69 \pm 1.94$ & $11.22 \pm 2.12$ & $* * *$ \\
\hline
\end{tabular}

Legend: $* \mathrm{P}>0.05, * * \mathrm{P}<0.01, * * * \mathrm{P}<0.001$, ns not significant

Meat colour (Table 7) CIE $L^{*}$ (lightness) 24h after slaughter of MLT was similar in both breeds, whereas colour of top round muscle 7 days post mortem was lighter $\left(\mathrm{CIE} L^{*}\right)$ in the Holstein $(\mathrm{P}<0.01)$. Consumers have tendency to decide in accordance to the meat colour, while they link pale and dark colour of the meat with the loss of freshness (Vieira et al., 2005). Values $a^{*}$ (redness) and $b^{*}$ (yellowness) $24 \mathrm{~h}$ post mortem of MLT $\left(a^{*} \mathrm{P}<0.05 ; b^{*} \mathrm{P}<0.01\right)$ and top round muscle $(a * \mathrm{P}<0.05 ; b * \mathrm{P}<0.001)$ were higher in the $\mathrm{H}$ veal. However,7 days after slaughter, values were greater in the $\mathrm{S}$ young bulls, which indicate redder colour. Yim et al. (2015a) also reported lighter meat in the Holstein (low $a^{*}$ and $b^{*}$ values). The veal industry demands lean colour of the meat with unique characteristics (Ngapo and Gariépy, 2006). We showed in this study lighter meat colour of the $\mathrm{H}$ calves, characterized by high $L^{*}$ values $(61.28$ for MLT and 61.08 for m.semimembranosus) and low $a^{*}$ and $b^{*}$ values. Meat colour is associated with the haemoglobin content, while higher contents of haemoglobin in the blood indicate darker colour of the muscle (Velik et al., 2010). In addition, meat colour could be correlated with $\mathrm{pH}$ value (Yim et al., 2015b). The $\mathrm{pH}$ value increases with decreasing meat lightness.

\section{CONCLUSIONS}

The aim of this study was to evaluate carcass and qualitative parameters of veal from the most used breeds in milking farm in Slovakia fedwith the most available fodder sources. We observed no significant differences in the slaughter parameters from the results of the Holstein $(n=10)$ and Slovak Simmental $(n=10)$ in this experiment. The results of the Holstein young bulls showed lower proportion of marrow bones $(12.04 \%)$ as well as lower proportion of separable fat $(6.65 \%)$. The highest meat proportion from the right-half carcass was found in the $\mathrm{S}$ veal $(67.56 \% ; 23.71 \mathrm{~kg})$. The proximate composition of $M$. longissimus thoracis reveals, that meat of the Slovak Simmental veal contains more moisture $(76.06 \% ; \mathrm{P}<0.01)$, lessproteins $(22.62 \% ; \mathrm{P}>0.05)$ as well as less intramuscular fat $(1.54 \% ; \mathrm{P}>0.05)$. Calves of the $\mathrm{S}$ had also darker and redder meat represented in MLT 7 days post mortem with lower $L^{*}$ values $(52.46$; $\mathrm{P}<0.01)$, higher $a^{*}$ $(1.66 ; \mathrm{P}>0.05)$ and $b *(10.28 ; \mathrm{P}<0.001)$ values. In addition, samples of Slovak Simmental veal showed higher electrical conductivity -2 in MLT $(\mathrm{P}<0.001)$ and $\mathrm{SM}(\mathrm{P}<0.01)$ and the lower $\mathrm{pH}_{24}$ value $(\mathrm{P}<0.001)$. As expected, higher content of intramuscular fat resulted to more tender meat in the Holstein loin muscle $(\mathrm{P}<0.001)$. Likewise, we found in the Holstein samples of $M$. longissimus thoracis and M. semimembranosus higher rate of lipid degradation after 9 days of storage $(\mathrm{P}>0.05)$.

Acknowledgements: Financial support of this study was provided by KEGA No. 015SPU-4/2019.

\section{REFERENCES}

AUGUSTINI, CH., FISCHER, K. 2000. Ageing and sensory properties of meat Fleischwirtschaft international: Journal for Meat Production and Meat Processing, 4, 32-35. ISSN 0179-2415

BARTON, L., TESLÍK, V., ZAHRÁDKOVÁ, R., BUREŠ, D. 2003. Growth, feed efficiency and carcass characteristics of Czech Pied and Holstein bulls. Czech Journal of Animal Science, 48 (11), 459-465. ISSN 1212-1819

BRUCE, H. L., SCOTT, J. R., THOMPSON, J. M. Application of an exponential model to early post mortem bovine muscle $\mathrm{pH}$ decline. Meat Science, 58(1), 39 44. http://dx.doi.org/10.1016/S0309-1740(00)00128-5

ÇATIKKAŞ, E. - KOÇ, A. 2017. Fattening performance, carcass characteristics and beef quality of Holstein-friesian, Brown-swiss and Simmental bulls. In Adü Ziraat Derg, vol. 14(1), p. 59-64. http://dx.doi.org/10.25308/aduziraat.296928 Council Regulation (EC) No. 566/2008 of $18^{\text {th }}$ June, 2008 amending Regulation (EC) No 1234/2007 establishing a common organization of agricultural markets and on specific provisions for certain agricultural products (Single CMO Regulation) Official J. European Communities. 2008:L 121/121-L 121/131
ČÍTEK, J., ŠOCH, M. 2002. Odchov telat. Praha: Ústav zemědělských a potravinářských informací, 40 p. ISBN 80-7271-121-0

FEINER, G. 2006. Meat products handbook: Practical science and technology. First published 2006, Woodhead Publishing Limited and CRC Press LLC. 672 p. http://dx.doi.org/10.1201/9781439824245

FIEMS, L. O., CAMPENEERE, S. DE., SMET, S. DE., VAN DE VOORDE, G., VANACKER, J. M., BOUCQUÉ, CH. V. 2000. Relationship between fat depots in carcasses of beef bulls and effect on meat colour and tenderness. Meat Science 56(1), 41-47. http://dx.doi.org/10.1016/S0309-1740(00)00017-6

FRANC, C, BARTOŠ, L., HANYŠ, Z., TOMEŠ, Z. 1988. Pre-slaughter social activity of young bulls relating to the occurrence of dark-cutting beef. Animal Science, 46(2), 153-161. http://dx.doi.org/10.1017/S0003356100042203

Government Regulation (SR) Decree No. 270/2003 of the coll. Of Slovak Republic of $9^{\text {th }}$ July establishing minimum standards for the protection of the calves.

HAŠČÍK, P., TREMBECKÁ, L., BOBKO, M., KAČÁNIOVÁ, M., BUČKO, O. TKÁČOVÁ, J., KUNOVÁ, S. 2015. Effect of different dietary supplements of selected quality indicators of chicken meat. Potravinarstvo Scientific Journal for Food Industry, 9(1), 427-434. http://dx.doi.org/10.5219/517

CHLÁDEK, G. - INGR, I. 2003. Meat quality and beef production parameters of Holstein steers fattened up to 10-12 months of age. Czech Journal of Animal Science, 48(11), 475-480. ISSN 1211-8516

CHO, S., KANG, S. M., SEONG, P., KANG, G., CHOI, S., KWON, E., MOON, S., KIM, D., PARK, B. 2014. Physico-chemical Meat Qualities of Loin and Top Round Beef from Holstein Calves with Different Slaughtering Ages. Korean Journal for Food Science of Animal Resources, 34 (5), 674-682. http://dx.doi.org/10.5851/kosfa.2014.34.5.674

JEDLIČKA, J. 1988. Kvalita mäsa. Bratislava: Príroda, č.publ. 6625-SÚKK $121 / \mathrm{I}-88,232 \mathrm{p}$

JEREMIAH, L. E., DUGAN, M. E. R., AALHUS, J. L., GIBSON, L. L. 2003 Assessment of the chemical and cooking properties of the major beef muscle and muscle groups. Meat Science, 65(3), 985-992. http://dx.doi.org/10.1016/S03091740(02)00308-X

LI, K., MCKEITH, A. G., SHEN, C., MCKEITH, R. 2018. A Comparison Study of Quality Attributes of Ground Beef and Veal Patties and Thermal Inactivation of Escherichia coli O157:H7 after Double Pan-Broiling Under Dynamic Conditions. Foods, 7(1), 1-13. http://dx.doi.org/10.3390/foods7010001

MARCINČ́KK S., SOKOL J., TUREK P., POPELKA P., NAGY J. 2006 Determination of malondialdehyde in pork meat using solid phase extraction and HPLC. Chemické Listy, 100, 528-532. ISSN 1213-7103

MASR, 2002. Decree of the Ministry of Agriculture of the Slovak Republic Grocery codex, year XXXIV, p. 1-11.

MOJTO, J., ZAUJEC, K. 2003. Analýza krehkosti (strižnej sily) hovädzieho mäsa jatočnej populácie. Maso, 1, 25 - 27. ISSN 1210-4086

NGAPO, T. M., GARIÉPY, C. 2006. Factors affecting the meat quality of veal: Review. Journal of the Science of Food and Agriculture, 86, 1412-1431 http://dx.doi.org/10.1002/jsfa.2507

PAlO, D. P., MAGGiOlinO, A., TATEO, A., CENTODUCATI, P. 2014 Influence of Gas Mixture on Quality and Shelf Life of Veal Calf Meat. Italian Journal of Animal Science, 13(2), 226-233. http://dx.doi.org/10.4081/ijas.2014.3129

PEREZ-CHABELA, M.L., GUERRERO, I., GUTIERREZ-RUIZ, M.C., BETANCOURT-RULE, J.M. 2005. Effect of calcium chloride marination and collagen content on beef, horse, rabbit and hen meat hardness. Journal of Muscle Foods, 16, 141-154. http://dx.doi.org/10.1111/j.1745-4573.2005.01204.x PIPEK, P. 1998. Technologie masa II. 1. vyd. Kostelní Vydří: Karmelitánské nakladatelství v Kostelním Vydří, 360 p. ISBN 80-7192-283-8.

SANTOS, P.V., PARIS, W., MENEZES, L. F. G., VONZ, D., SILVEIRA, M. F., TUBIN, J. 2013. Carcass physical composition and meat quality of Holstein calves, terminated in different finishing systems and slaughter weights. Ciência e Agrotecnologia, 37(5), 443-450. $\quad$ http://dx.doi.org/10.1590/S1413$\underline{70542013000500008}$ 
SAS INSTITUTE Inc. (2011) Base SAS ${ }^{8} 9.3$ Procedures Guide. Cary, NC: SAS Institute Inc., Carry. NC. USA

SKŘIVANOVÁ, E., MAROUNEK, M., SMET, S. D., RAES, K. 2007. Influence of dietary selenium and vitamin E on quality of veal. Meat Science, 76(3), 495500. http://dx.doi.org/10.1016/j.meatsci.2007.01.003

SOMMER, A., ANTAL, J., CHOVANEC, J., PAJTÁŠ, M., ŠKULTÉTY, M. 1975. Výživa hovädzieho dobytka. Bratislava: Príroda, p. 213. STEINHAUSER L., NEŇOVSKÝ, R., BYSTRICKÝ, P., CABADAJ, R., ČERNÝ, H., DVOŘÁK, J. et al. 2000. Produkce masa. Steinhauser - Last, Tišňov: Vyd. potravinářské literatúry, 464 p. ISBN 80-900260-7-9.

VAVRIŠ́́NOVÁ, K., PRÍVARA, S., ČUBOŇ, J., FOLTYS, V. 2013.Veal quality and fatty acids content in Holstein calves at different diets. Veterinarija ir zootechnika, 61(83), 89-95. ISSN 1392-2130

VELIK, M., KITZER, R., STUHLPFARRER, A., GALLNBÖCK, M., STEINWIDDER, A. 2010. Colour of calf meat fattened with whole milk influence factors and measures for preventing dark veal colour - Zwischenbericht des BMLFUW Forschungs projekts Nr. 100523.

VIEIRA, C., GARCÍA, M. D., CERDEÑO, A., MANTECÓN, A. R. 2005. Effect of diet composition and slaughter weight on animal performance, carcass and meat quality, and fatty acid composition in veal calves. Livestock Production Science, 93(3), 263-275. http://dx.doi.org/10.1016/j.livprodsci.2004.11.020

VOJTAŠŠÁKOVÁ, A., KOVÁČIKOVÁ, E., PASTOROVÁ, J., MOSNÁČKOVÁ, J., SIMONOVÁ, E., HOLČÍKOVÁ, K. 2002. Mäso jatočných zvierat: potravinové tabul'ky. ÚVIIP Nitra: vydavatel'stvo NOI, 292 p. ISBN 8089088-10-4

YIM, D.G., CHUNG, E.C., CHUNG, K.Y. 2015a. Meat quality of Loin and Top Round Muscles from the Hanwoo and Holstein Veal Calves. Korean Journal for Food Science of Animal Resources, 35(6), 731-737. http://dx.doi.org/10.5851/kosfa.2015.35.6.731

YIM, D. G., PARK, S. W., CHUNG, K. Y. 2015b. Physicochemical traits of Holstein loin and top round veal from two slaughter age groups.Journal of Animal Science and Technology, 57(24), 1-5. http://dx.doi.org/10.1186/s40781$\underline{015-0058-0}$ 